\title{
Assessment of Concurrent Cellular Oxidative Stress with the Body Weight Gain in Serum of Obese Patients Undergoing to Surgical / Non-Surgical Strategies for Reducing an Excess Weight
}

\author{
Ahssan Ali Lefta, "Rasha Hasan Jasim \\ *Department of Chemistry-Factually of Education for Girls-University of Kufa-Iraq
}

\begin{abstract}
Obesity is not a single disease, there are 300 different genes were linked to obesity, in addition to several environmental factors could be associate to obesity happening, while most considerations common indicted to the fact that obesity process is a result of an interaction of environmental factors with the genetic predisposition lead to fat accumulation and increased in the adipose tissues. Under normal conditions ROS and RNS are produced. This production balanced by number of acceptor electron molecules that synthesized cellular. An injured tissues caused by disorders in the balance between the production of reactive species of known as free radicals and antioxidants which is the defensive mechanism, through this status the raise in the oxidation processes will occur in contrast to the reduction in the synthesis of defense molecules.
\end{abstract}

Subjects: 47patients (33.28 \pm 7.424 years with age range 34 years) and 24 healthy individuals (25.96 \pm 3.983 years with age range 13 years) were enrolled in the present study. Patients with BMI more than $30 \mathrm{Kg} / \mathrm{m}^{2}$ $\left(45.179 \pm 9.09 \mathrm{Kg} / \mathrm{m}^{2}\right.$, and $38.7 \mathrm{Kg} / \mathrm{m}^{2}$ as BMI range); haven 't diabetes mellitus, they aren't subjected to obesity surgical operation before. Control group might at approximate age range with the patients group, with similar food style. Average BMI of no smoking, no alcohol drinking healthy group was $18.5 \mathrm{Kg} / \mathrm{m}^{2}(22.829 \pm 0.752$ $\left.K g / m^{2}\right)$.

Results: Evaluation of the MDA concentrations revealed a significant increase $(p<0.05)$ in patients of obesity when compared with healthy individuals. From the statistical analysis of the obese patients group, a positive correlation between the serum MDA concentration with BMI raise $(r=86.925 \%$ at $p<0.001)$. while highly significant differences $(p<0.05)$ were noticed at the two study's groups were compared together, when both of ceruloplasmin oxidase activity and concentration were examined. It has been monitoring the positive relations between BMI levels and both of the activity and concentration of ceruloplasmin oxidase enzyme in the sera samples of obese patients group, where the activity and concentration of ceruloplasmin oxidase rose in 76.112 $\%$ and $68.869 \%$ (at $p<0.05)$ of the total cases of patients. The Person's correlation demonstrated significant positive relationship in those of obese patients $(r=0.828$ at $p<0.005)$, But not in those of controls group.

Conclusion: MDA levels is affected during the overweight gain; and they correlated directly to BMI. CP acts as acute phase protein in response to weight gain, in addition to its an antioxidant role to accommodate the overflow of electrons (free radicals) formed during the process of obesity.

Keywords: Obese, Malondialdehyde, Ceruloplasmin, Surgical Operation, Bypass, Sleeve and Balloon

\section{INTRODUCTION}

Overweight and obesity are chronic diseases with specific behaviors, originally; due to weight problems that begin with childhood ${ }^{(1)}$.Overweight and obesity are the result of surplus energy which is stored in the body over time in the form of fat ${ }^{(2)}$.Obesity is the accumulation of an excessive amount of the body fat; thus, weight increases in anyone more than $20 \%$ over the weight of natural persons as a result of fat accumulation ${ }^{(3)}$.As such an overweight means increasing the body weight compared with the level of weight accepted in the normal ${ }^{(4)}$.It is believed that obesity is a result for losing of ability to correct habits of eating ${ }^{(5)}$. Obesity is not a single disease, there are 300 different genes that are linked to obesity, in addition to several environmental factors that could be associated with obesity cases $^{(6)}$.Most considerations are commonly indicted to the fact that obesity process is a result of an interaction of environmental factors with the genetic predisposition that lead to fat accumulation and increase in the adipose tissues ${ }^{(7)}$. There are many techniques that could be followed to reduce body weight using diet, and they include: calories input decreasing (little food, taking drug to weak absorption or an appetite), promoting input of calories (increase consumption of nutrition foods); this strategy could contribute in the activation of fat catabolism ${ }^{(7)}$. 
Under normal conditions, reactive oxygen and nitrogen species (ROS and RNS) are produced. This production is balanced by number of acceptor electron molecules that synthesized cellular. Injured tissues are caused by disorders in the balance between the production of reactive species of known as free radicals and antioxidants which is the defensive mechanism. Through this status raise in the oxidation processes will occur in contrast to the reduction in the synthesis of defense molecules ${ }^{(8)}$. The outcome of this status leads to oxidative stress, and then cellular oxidative damage ${ }^{(9) .}$

Free radicals are chemical particles containing unpaired electrons (single) and will be paramagnetic. Most of oxygen is derived from the free radical related biological cell and is not stable, short-lived and with high degree of the effectiveness. The harmful roles of free radicals in many physiological and pathophysiological phenomena are linked to redox status cell modification ${ }^{(10)}$. The external sources of free radicals production include $u v$ radiation, ozone, pollution, alcohol intake, cigarettes smoking, excess iron, pesticides, mycotoxins and some medicines ${ }^{(11)}$. ROS could enhance cellular damage by modifying fats, proteins and DNA characteristics. ROS can influence the health cell and vitality or induce a variety of cellular responses where leading, at last, to cell death by necrosis or apoptosis. Oxidative damage of any biomolecules, if unchecked; probably is responsible of the development to the disease ${ }^{(12)}$.

ROS may be responsible for many pathological cases that include neurodegenerative disease like Alzheimer's and Parkinson's disease, atherosclerosis, inflammatory conditions, certain cancers, diabetes mellitus, pulmonary renal and heart diseases and process of aging ${ }^{(13)}$.

Malondialdehyde (MDA) is a high effective molecule, three carbon dialdehyde produced as a result of peroxidation of polyunsaturated fatty acid, as well as during the arachidonic acid metabolism for the synthesis of prostaglandins. MDA could illustrate its baleful action in the cell through bind to the functional groups in the proteins, lipoproteins, RNA and DNA molecules ${ }^{(14,15)}$.Evaluating MDA levels in the biological materials could be used as an important indicator for various diseases in vitro or vivo of lipid peroxidation, where MDA could be an output of natural lipid peroxidation ${ }^{(15)}$.Lipid peroxidation is the best stable mechanism of cellular injury in the organism cells, that is used as an indicator of oxidative stress in the cells and tissues. Polyunsaturated fatty acids are unstable and degrade in the forms of complex series of compounds, i.e. MDA, by cyclooxygenase catalysis ${ }^{(15,16)}$.MDA can be present in most of the biological samples including foodstuffs, serum, plasma, tissues and urine from lipid peroxidation, production of MDA as an active molecules from different lipid peroxidation at many tissues, makes it as a sensitive and comfortable molecule for quantitative measurements of lipid peroxide concentration in many samples of the biological systems ${ }^{(17,18)}$.

Ceruloplasmin $(\mathrm{Cp})$ is a plentiful blue $\alpha_{2}$-glycoprotein that contains more than $95 \%$ of copper found in the plasma of all types of vertebrates ${ }^{(19,20)}$. Cp is synthesized mainly in the liver as single chain of polypeptide of 1046 amino acids, and is excreted in the plasma with 6 or 7 atoms of copper binding in the one molecule ${ }^{(21)} . \mathrm{Cp}$ is a molecule association between iron and copper metabolism, also known as serum multicopper protein and exhibition ferroxidase activity, superoxidase activity and amino oxidase activity ${ }^{(20,21)}$. It seems to be more important for copper storage pool of that transport protein, integrates iron and copper homeostasis ${ }^{(22)}$. However, the physiological role of $\mathrm{Cp}$ is not known but it may include activity of the extracellular antioxidant by encouraging iron mobilization and then to prevent metal catalysts free radicals tissue damage ${ }^{(23)}$. Recent studies confirm the absorb food copper which is the transfer by plasma protein carriers like transcuprein, albumin and $\mathrm{Cp}$ from the intestine to kidney and liver. $\mathrm{Cp}$ is involved in the first place of the copper transporting from the liver to other organs ${ }^{(24)}$.The decrease in the concentration of serum $\mathrm{Cp}$ is considered as diagnosis indicator of Wilson's disease, while the increase of it concentrations has been reported in patients with macular degenerations and in a variety of tumors and inflammatory conditions such as cancer, leukemia, Hodgkin's lymphoma, primary biliary cirrhosis, systemic lupus erythematous and rheumatoid arthritis $(20,25)$

\section{SUbJECTS AND METHODS}

Forty seven patients $(\mathbf{3 3 . 2 8} \pm \mathbf{7 . 4 2 4}$ years with age range 34 years) and 24 healthy individuals $(\mathbf{2 5 . 9 6}$ \pm 3.983 years with age range 13 years) were enrolled in the present study. Patients with BMI more than $30 \mathrm{Kg} / \mathrm{m}^{2}\left(\mathbf{4 5 . 1 7 9} \pm \mathbf{9 . 0 9} \mathrm{Kg} / \mathrm{m}^{2}\right.$, and $38.7 \mathrm{Kg} / \mathrm{m}^{2}$ as BMI range); haven't diabetes mellitus, they aren't subjected to obesity surgical operation before. In order to treat an excess of their body weight or health problems, the present study patients were underwent to the neumours treatment kinds 
(surgically or non surgical operations). The patients' group is classified into 3 subgroups according to the type of treatment; firstly 3 patients were treated with bypass surgery, the second subgroup that included 22 patients, is underwent to sleeve surgery, while the last subgroup that included 22 patients, is treated by balloon strategic opinion. Selection of healthy individuals as a control group is based upon several criteria included: an absence of major medical or surgical illness in the previous 5 years, no hospital admissions, no current medication, and a subjective perception of good health as determined by health questionnaire. More than, control group might at approximate age range with the patients group, with similar food style. Average BMI of no smoking, no alcohol drinking healthy group was $18.5 \mathrm{Kg} / \mathrm{m}^{2}\left(\mathbf{2 2 . 8 2 9} \pm \mathbf{0 . 7 5 2} \mathbf{~ K g} / \mathbf{m}^{2}\right)$. Information of study groups data was summarized in the Table 1.

Table1. Age and BMI Details in the Patients and Controls Groups

\begin{tabular}{|r|r|r|r|r|r|r|}
\hline \multirow{2}{*}{ Groups (n) } & \multicolumn{3}{|c|}{ Age (year) } & \multicolumn{2}{c|}{ BMI ( Kg/m $\left.{ }^{2}\right)$} \\
\cline { 2 - 7 } & Mean \pm S.D. & Min. - Max. & Range & Mean \pm S.D. & Min. - Max. & Range \\
\hline Patients 47 & $33.28 \pm 7.424$ & $14-48$ & 34 & $45.179 \pm 9.09$ & $30-68.7$ & 38.7 \\
\hline Healthy 24 & $25.96 \pm 3.983$ & $22-35$ & 13 & $22.829 \pm 0.752$ & $21.5-24.4$ & 2.9 \\
\hline
\end{tabular}

Bypass surgical operation patients group included 3 female only, while sleeve surgical operation patients group were included 15 females and 7 males, finally the group of patients who treated with balloon strategic consisted of 14 females and 8 males. Five $\mathrm{ml}$ of venous blood samples were collected from the study groups' individuals after fasting period more than eight hours. Sera of patient samples were collected from many private hospitals in the Najaf City, Iraq. Selection of the study cases was based upon the clinical diagnosis and the opinion of specialist doctors who identified the best type of treatment for the study cases. The levels of serum MDA was measured by the TBARS assay(26), while the activity of ceruloplasmin oxidase was determined in the study sera samples using the modified Rice method(27).The statistical analysis was done using the Statistical Package for the Social Science (SPSS) software for windows, Version 19.0. The results were expressed as mean \pm standard deviation (Mean \pm S.D.), maximum, minimum and range. The two study groups data were analyzed with Student's independent $\boldsymbol{t}$-test. One way analysis of variance (ANOVA) was used to compare parameters in different studied subgroups. Pearson's correlation was applied to determined the relations among the laboratory parameters of the present study, significance was determined regression. $p$-values less than $5 \%(\mathrm{p}<0.05)$ were considered as statistically significant.

\section{RESUlTS AND DisCUSSION}

Obesity as a pathological process is concurred with cellular oxidative stress occurring, through stimulating of oxidative stress system, in turn, oxidative stress is associated with an irregular production of adipokines, which contributes to the development of the metabolic syndrome ${ }^{(28)}$.There are several mechanisms that could contribute together to explain the formation of free radicals (as a result to the cellular oxidative stress) during the obesity process. Primarily, an over excess in the body weight associated oxidative stress is due to the presence of excessive adipose tissue itself, because adipocytes and preadipocytes have been identified as a source of proinflammatory proteins "cytokines", because obesity is considered a state of chronic inflammation. Elevation of reactive oxygen and nitrogen species in the cells is extrusive commensurate to the cytokines levels, because the last are potent stimulators for production of free radicals by macrophages and monocytes; moreover, cytokines, especially TNF- $\alpha$; decreased the activity of C-reactive proteins, like ceruloplasmin, that will increase the interaction of electrons with oxygen to generate superoxide anion ${ }^{(29)}$. In addition, during an increase in the fat accumulation cellular damage could occur due to pressure effect from fat cells, this damage leads to high production of cytokines which generates free radicals in the tissues, then increasing the lipid peroxidation rate ${ }^{(30)}$.

In the obese individuals, oxygen consumption is increased as a result to the elevation in the mechanical load and myocardial metabolism ${ }^{(31)}$, the worst result to the increasing in the oxygen consumption is the production of reactive oxygen species as malondialdehyde, superoxide, hydroxyl radical, and hydrogen peroxide derived from the increase in mitochondrial respiration and, from the loss of electrons produced in the electron transport chain, resulting in the formation of superoxide radical $^{(32,33)}$.

Type of diet, especially high fats diet, is considered another probable cause for altering oxygen metabolism and increasing the production of reactive oxygen species during obesity. In the fatty food, fatty deposits are vulnerable to suffer oxidation reactions, at this status, production of free radicals will increase, these reactive species will augment the antioxidant capacity of the cell ${ }^{(34)}$. 
Obesity proceeded among various disorders that affect mitochondrial metabolism ${ }^{(35)}$, when it enhances reactive oxygen species generation and development of cellular oxidative stress. Dynamically, mitochondria provides the required energy for almost the cellular processes that ultimately permit the carrying out of physiological functions, in addition to their role in apoptosis process. Mitochondrial oxidative phosphorylation is very efficient process, although, a small percentage of electrons may prematurely reduce oxygen, forming potentially toxic free radicals, impairing mitochondrial function. Vitally, protons can be reintroduced into the mitochondrial matrix through different uncoupling proteins (UCP-1, -2, and -3), affecting the control of free radical production in mitochondria ${ }^{(36)}$. Uncoupling proteins possess an amino acid sequence that is utilized to identify potential mitochondrial carriers. Human UCP-3 protects the mitochondria of lipotoxicity in cases of increased concentrations of free fatty acids "as a component of triglycerides" in the matrix, because it leads to the intermembrane space occurring and dysfunction of mitochondrial respiratory chain through inhibits translocation of adenine nucleotides and promotes the generation of superoxide $(37,38)$

MDA presented as a decent marker in assessment of oxidative stress occurs during many pathological and non pathological conditions ${ }^{(22,39-42)}$.Student's $\boldsymbol{t}$-test was applied to test the results of serum MDA levels' changes between obese patients and control groups. Evaluation of the MDA concentrations revealed a significant increase $(\mathbf{p}<\mathbf{0 . 0 5})$ in patients of obesity when compared with healthy individuals, as shown in Table 2.

Table2. Levels of MDA Concentration In Sera of Obese Patients and Controls Subjects (Mean \pm S.D.)

\begin{tabular}{|l|l|l|l|l|}
\hline Subjects (n) & $\begin{array}{l}\text { MDA Concentration }(\mathrm{mM}) \\
\text { Mean } \pm \text { S.D. }\end{array}$ & Min.-Max. & Range & $\mathrm{p}$ \\
\hline Obese 47 & $0.388 \pm 0.090$ & $0.166-0.514$ & 0.348 & \\
\hline Control 24 & $0.090 \pm 0.058$ & $0.016-0.252$ & 0.236 & 0.000 \\
\hline
\end{tabular}

These results agreed with the several studies which were evaluated MDA levels in different diseases ${ }^{(22,43)}$, on the other hand the current work results were disagreed with other clinical studies ${ }^{(40)}$.Gender was found to have no effect on serum MDA concentrations in patients and control groups, when Analysis of Variances (ANOVA) test failed to exhibit significant changes among male and female within same subgroups (Table 3).

Table3. Comparison of MDA Levels in Male and Female of Patients and Controls Individuals

\begin{tabular}{|l|l|l|l|l|l|}
\hline Subjects (n) & Gender $(\mathrm{n})$ & $\begin{array}{l}\text { MDA Concentration }(\mathrm{mM}) \\
\text { Mean } \pm \text { S.D. }\end{array}$ & Min.-Max. & Range & $\mathrm{p}$ \\
\hline \multirow{3}{*}{ Obese 47} & Female 31 & $0.384 \pm 0.088$ & $0.166-0.514$ & 0.348 & 0.418 For 1vs2 \\
\cline { 2 - 6 } & Male 16 & $0.362 \pm 0.084$ & $0.217-0.491$ & 0.274 & 0.497 For 3vs4 \\
\hline \multirow{3}{*}{ Control 24 } & Female 8 & $0.074 \pm 0.029$ & $0.048-0.143$ & 0.095 & 0.000 For 1vs3 \\
\cline { 2 - 6 } & Male 16 & $0.097 \pm 0.068$ & $0.016-0.252$ & 0.236 & 0.000 For 2vs4 \\
\hline
\end{tabular}

1: Female Patients, 2: Male Patients, 3: Healthy Females, and 4: Healthy Males. The Mean Difference is Significant at 0.05 Level

Nemours studies agreed with the finding of the present work in the fact of gender type had no effect in the levels of MDA, neither in patients nor in healthy subjects ${ }^{(44)}$.

In order to verify the changes of the MDA concentrations with the BMI levels, linear regression analysis was applied to study the relationship of serum MDA to BMI in both of patients and control groups. From the statistical analysis of the obese patients group, a positive correlation between the serum MDA concentration with BMI raise $(\mathbf{r}=\mathbf{8 6 . 9 2 5} \%$ at $\mathbf{p}<\mathbf{0 . 0 0 1})$ was observed (Figure 3(A)). No such results were noted when the serum MDA concentration of the control group were correlated to their BMI levels, as shown in Figure 3 (B).
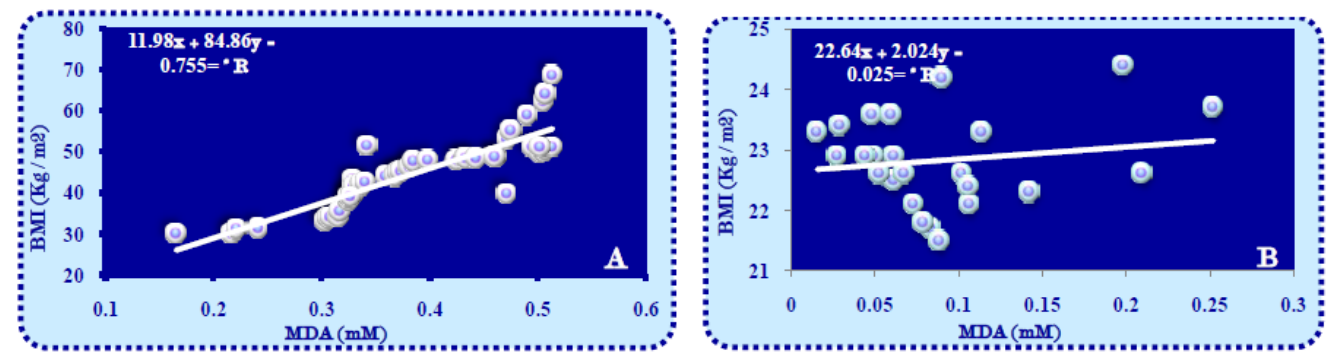

Fig3. Correlation of BM Iand Serum MDA in (A): Patients and (B): Controls 
Assessment of Concurrent Cellular Oxidative Stress with the Body Weight Gain in Serum of Obese Patients Undergoing to Surgical / Non-Surgical Strategies for Reducing an Excess Weight

This result coincided with $\mathrm{Pihl}^{(45)}$ and Codoner-Franch ${ }^{(46)}$ studies, which recorded a positive correlation of excess in the BMI to the elevation in the levels of MDA.

Because of the lack of researches addressing the fact MDA levels and linked to the weight applicants patients for a weight-loss operations, the current study represents the first step in the tracking the cellular stress concurrent with different BMI levels to provide a full concept of what happens in the body of person applying for a weight-loss operations, and what will happen then.

Regardless of the type of techniques followed to treat the increase in the BMI, all the female patient cases illustrated high levels of MDA at compared to healthy females $(\mathbf{p}<\mathbf{0 . 0 0 5})$, as observed in Table 3 and Figure 4 (A). Two young male patients only were illustrated levels of MDA adjacent to cutoff MDA value, this note enhanced the previous observation about the elevations in the sera MDA of obese patients comparison to healthy persons.
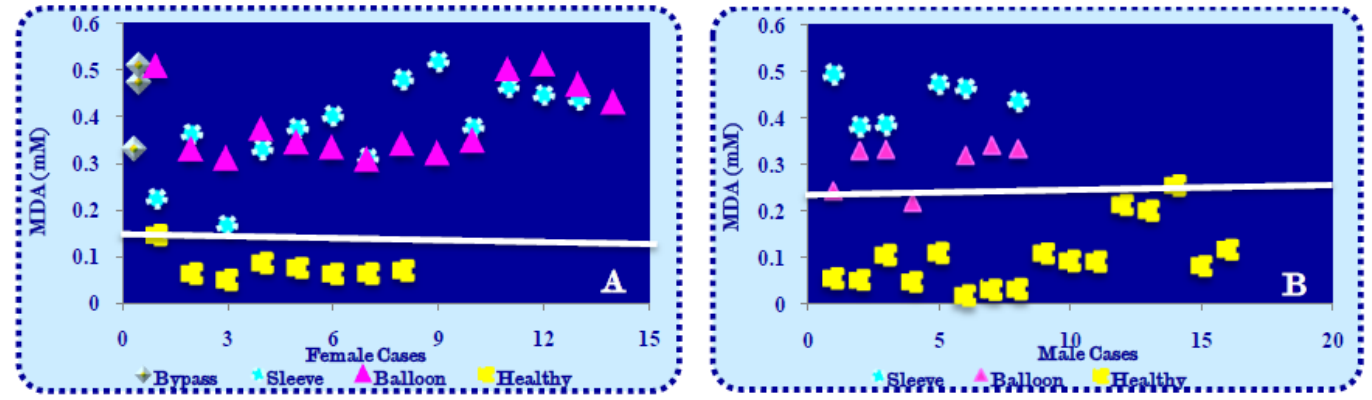

Fig4. Gender Differences of Serum MDA Levels in Obese Patients According to the Type of Treatment Strategies

Ceruloplasmin as one of the most important blood proteins was evaluated in many researches according to its functionally diverse. These functions ranged from its role in the blood coagulation, ceruloplasmin binding copper transporting as well iron homeostasis ${ }^{(47)}$, furthermore its involved in protection of angiogenesis from tissue injury ${ }^{(47)}$. One of the acute phase proteins and antioxidant were the major published roles ceruloplasmin ${ }^{(22,48)}$.According to Student's t-test analysis, highly significant differences $(\mathbf{p}<\mathbf{0 . 0 5})$ were noticed at the two study's groups were compared together, when both of ceruloplasmin oxidase activity and concentration were examined, as shown in Tables 4 and 5; respectively. This result agreed with the study of $\operatorname{Giner}^{(49)}$; on the other hand, it was violate the results of Bharat kumar and Nobili studies ${ }^{(50,51)}$.

Table4. Levels of Cp Activity In Sera of Obese Patients and Controls Subjects (Mean \pm S.D.)

\begin{tabular}{|c|c|c|c|c|}
\hline Subjects (n) & $\begin{array}{c}\text { Ceruloplasmin Activity (U/L) } \\
\text { Mean } \pm \text { S.D. }\end{array}$ & Min.-Max. & Range & p \\
\hline Obese 47 & $65.085 \pm 27.476$ & $25.479-130.890$ & 105.411 & \multirow{2}{*}{0.000} \\
\hline Control 24 & $40.110 \pm 19.581$ & $12.565-92.844$ & 80.279 & 0.000 \\
\hline
\end{tabular}

Table5. Levels of Cp Concentration In Sera of Obese Patients and Controls Subjects(Mean \pm S.D.)

\begin{tabular}{|c|c|c|c|c|}
\hline Subjects (n) & $\begin{array}{c}\text { Ceruloplasmin Concentration (g/L) } \\
\text { Mean } \pm \text { S.D. }\end{array}$ & Min.-Max. & Range & $\mathrm{p}$ \\
\hline Obese 47 & $13.258 \pm 6.107$ & $5.162-28.175$ & 23.013 & \multirow{2}{*}{0.000} \\
\hline Control 24 & $7.594 \pm 4.422$ & $1.750-19.512$ & 17.762 & 0.000 \\
\hline
\end{tabular}

The rise of the ceruloplasmin levels in sera of obese patients samples could explain according to the fact, obesity is considered a disease of chronic low-grade inflammation ${ }^{(52)}$, and an inflammation status enhances the acute phase proteins synthesis in the liver. Moreover, ceruloplasmin catalyzed the oxidation of $\mathrm{Fe}^{2+}$ to $\mathrm{Fe}^{3+}$; this catalytic effect involving 4 of the 6 copper atoms associated with ceruloplasmin that employ 2 oxygen atoms as the terminal electron acceptor without the intermediacy of a partially reduced oxygen species, normally, this oxidase activity behavior increases during cellular injury, infection, and inflammation ${ }^{(48)}$. Thus, in the current study ceruloplasmin may act as acute phase protein in response to weight gain, in addition to its an antioxidant role to accommodate the overflow of electrons (free radicals) formed during the process of obesity.

It has been monitored that the positive relations between BMI levels and both of the activity and concentration of ceruloplasmin oxidase enzyme in the sera samples of obese patients group, where 
the activity and concentration of ceruloplasmin oxidase rose in $76.112 \%$ and $68.869 \%$ (at $\mathbf{p}<\mathbf{0 . 0 5}$ ) of the total cases of patients, as shown in Figures 5 (A) and 6 (A); respectively.
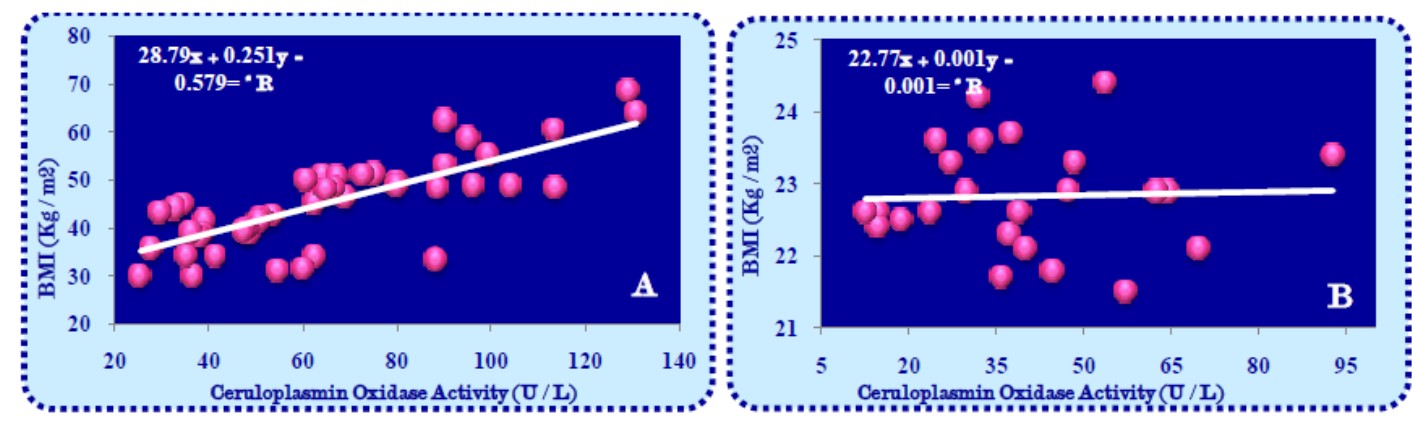

Fig5. Correlation of BMI and Serum Cp Activity in (A): Patients and (B): Controls

Serum ceruloplasmin oxidase activity and concentration of the healthy individuals group didn't show such correlations with the levels of BMI (Figures 5 (B) and 6 (B); respectively).
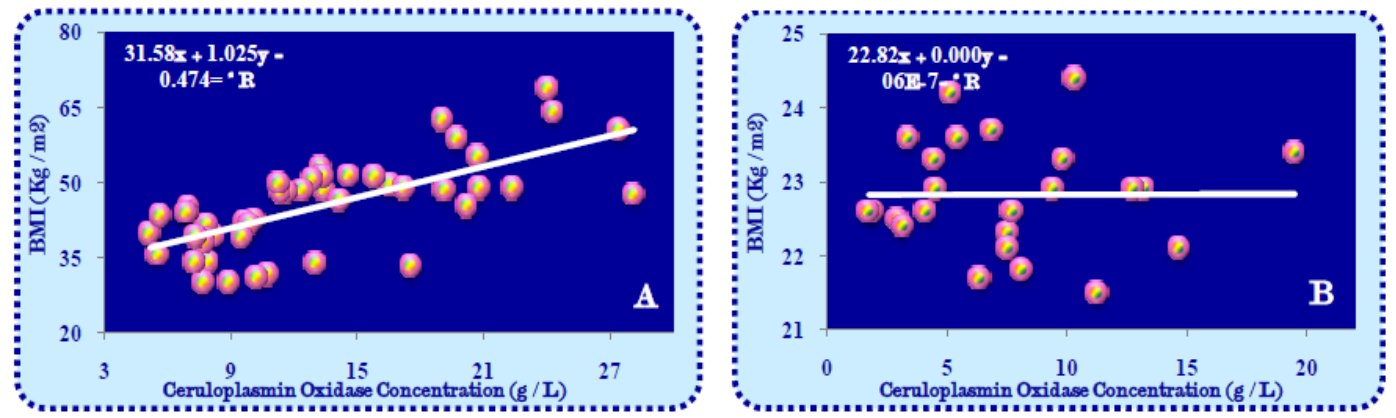

Fig6. Correlation of BMI and Serum Cp Concentration in (A):Patients and (B): Controls

This result agreed with the study of Tajik ${ }^{(53)}$, and the study of Marazziti ${ }^{(54)}$. Gender was observed to have no effect on serum ceruloplasmin oxidase activity in patients and control groups (Table6).

Table6. Comparison of Cp Activity in Male and Female of Patients and Controls Individuals

\begin{tabular}{|l|l|l|l|l|l|}
\hline Subjects n) & Gender (n) & $\begin{array}{l}\text { Cp activity (U/L) } \\
\text { Mean } \pm \text { S.D. }\end{array}$ & Min.-Max. & Range & $\mathrm{p}$ \\
\hline \multirow{3}{*}{ Obese 47 } & Female 31 & $68.513 \pm 29.248$ & $32.809-130.890$ & 98.081 & 0.191 For 1vs2 \\
\cline { 2 - 6 } & Male 16 & $58.442 \pm 23.085$ & $25.479-96.335$ & 70.856 & 0.134 For 3vs4 \\
\hline \multirow{3}{*}{ Control 4 } & Female 8 & $29.275 \pm 9.110$ & $14.659-40.139$ & 25.480 & 0.000 For 1vs3 \\
\cline { 2 - 6 } & Male 16 & $45.527 \pm 21.337$ & $12.565-92.844$ & 80.279 & 0.047 For 2vs4 \\
\hline
\end{tabular}

1: Female Patients, 2:Male Patients, 3: Healthy Females, and 4:Healthy Males. The Mean Difference is Significant at 0.05 Level

As shown in Table 7, the statistical evaluation failed to exhibit significant variation for serum ceruloplasmin oxidase concentration when female patients of obesity were compared with those of male patients, as well as; female and male of healthy individuals group, this result agreed with the study of Viorica ${ }^{(55)}$.

Table7. Comparison of Cp Levels in Male and Female of Patients and Controls Individuals

\begin{tabular}{|l|l|l|l|l|l|}
\hline $\begin{array}{l}\text { Subjects } \\
(\mathrm{n})\end{array}$ & Gender (n) & $\begin{array}{l}\text { Cp Concentration (g/L) } \\
\text { Mean } \pm \text { S.D. }\end{array}$ & Min.-Max. & Range & $\mathrm{p}$ \\
\hline \multirow{3}{*}{ Obese 47 } & Female 31 & $14.222 \pm 6.509$ & $6.912-28.175$ & 21.263 & 0.095 For 1vs2 \\
\cline { 2 - 6 } & Male 16 & $11.391 \pm 4.897$ & $5.162-20.212$ & 15.050 & 0.100 For 3vs4 \\
\hline \multirow{2}{*}{ Control 24 } & Female 8 & $4.965 \pm 2.109$ & $1.925-7.525$ & 5.600 & 0.000 For 1vs3 \\
\cline { 2 - 6 } & Male 16 & $8.908 \pm 4.730$ & $1.750-19.512$ & 17.762 & 0.307 For 2vs4 \\
\hline
\end{tabular}

1: Female Patients, 2:Male Patients, 3: Healthy Females, and 4:Healthy Males. The Mean Difference is Significant at 0.05 Level

For the purpose of monitoring the effectiveness of the gender of the patients and its relationship to the type of technologies used in the treatment of the increase in the BMI, levels of serum ceruloplasmin oxidase activity and ceruloplasmin oxidase concentration were distributed in each of two female and 
Assessment of Concurrent Cellular Oxidative Stress with the Body Weight Gain in Serum of Obese Patients Undergoing to Surgical / Non-Surgical Strategies for Reducing an Excess Weight

male subgroups according to the therapeutic taken in weight loss. Figures 7 (A) shows the levels of serum ceruloplasmin oxidase activity in the female patients subgroup were higher than cutoff value in regardless type of technique that followed to reduce weight, except; the five women (with the lost BMI among the female patients subgroup) underwent to stomach sleeve strategy to lose weight, in addition to the youngest female who treated by balloon technique to reduce BMI.
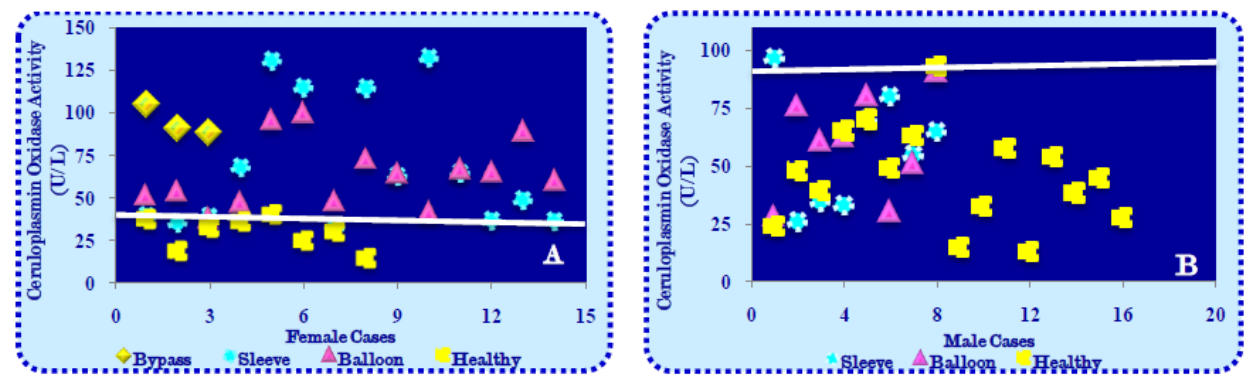

Fig7. Gender Differences of Serum Cp Activity Levels in Obese Patients According to the Type of Treatment Strategies

Figures 8 (A) illustrates the levels of serum ceruloplasmin oxidase concentrations of the obese women were higher those in the healthy female cases. In contract to female subgroup, male patients group failed to exhibit a significant differences between patients and healthy males in the levels of serum ceruloplasmin oxidase activity, where ceruloplasmin oxidase activity results of obese male were interfered with the results of healthy men subgroup (Figures 7 (B)).With the same opinions, the levels of serum ceruloplasmin oxidase concentrations of the obese men were asymptotical to the levels of the same parameter in serum of control men subgroup, as demonstrated in Figures 8 (B). The current work findings came compatible with the scientific facts that indicated estrogens mainly responsible for the increased level of serum ceruloplasmin, when they act as an inducer for synthesis of ceruloplasmin RNA templates causing subsequent increase in synthesis of the protein; while progesterone causes a less drastic rise ${ }^{(56)}$.

Yet, no study has been published on the relationship of ceruloplasmin oxidase with BMI of the two gender patients undergoing techniques for losing of the excess weight, except the present work.
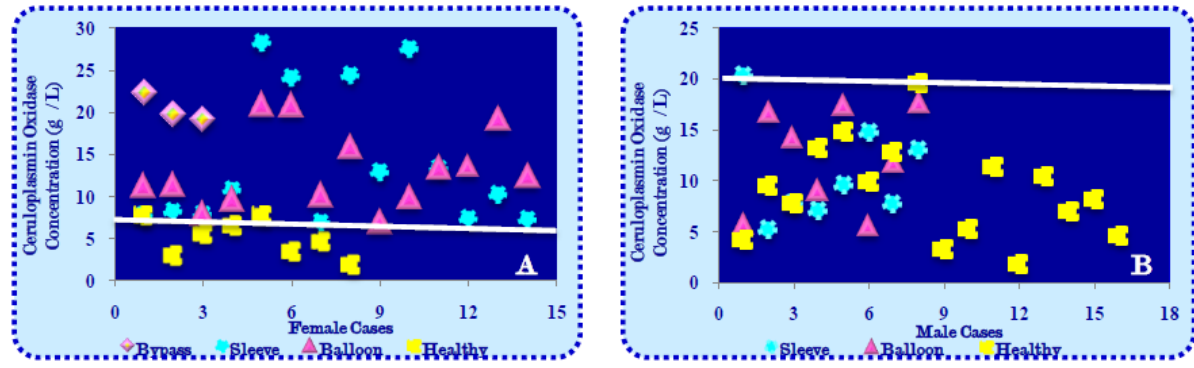

Fig8. Gender Differences of Serum Cp Concentration Levels in obese Patients According to the Type of Treatment Strategies

The Person's correlation demonstrated significant positive relationship in those of obese patients $(\mathbf{r}=$ $\mathbf{0 . 8 2 8}$ at $\mathbf{p}<\mathbf{0 . 0 0 5}$ ), but not in those of controls group Figure 9 (A) and (B) when MDA levels was correlated to the activity of ceruloplasmin oxidase.
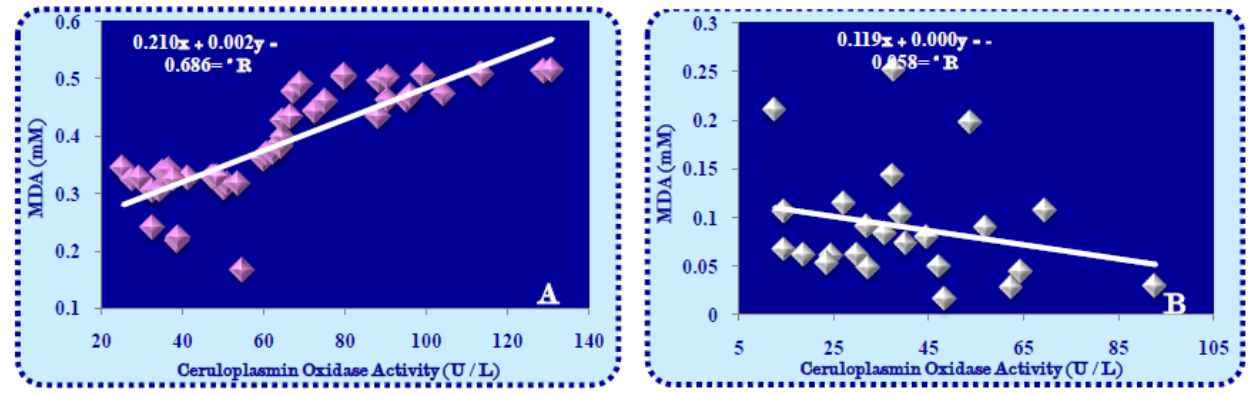

Fig9. Correlation of MDA Concentrations to Cp Activity in Sera Samples of (A):Obese and (B): Normal Individuals 
About 84.688 \% of the obese persons (at $\mathbf{p}<\mathbf{0 . 0 0 5}$ ) illustrated significant positive correlation at MDA concentration compared to ceruloplasmin oxidase concentration, as observed in Figure 10 (A).Negatively non significant correlation was noted when MDA and ceruloplasmin oxidase concentration is linked together at the cases of healthy controls, as shown in Figure 10 (B).
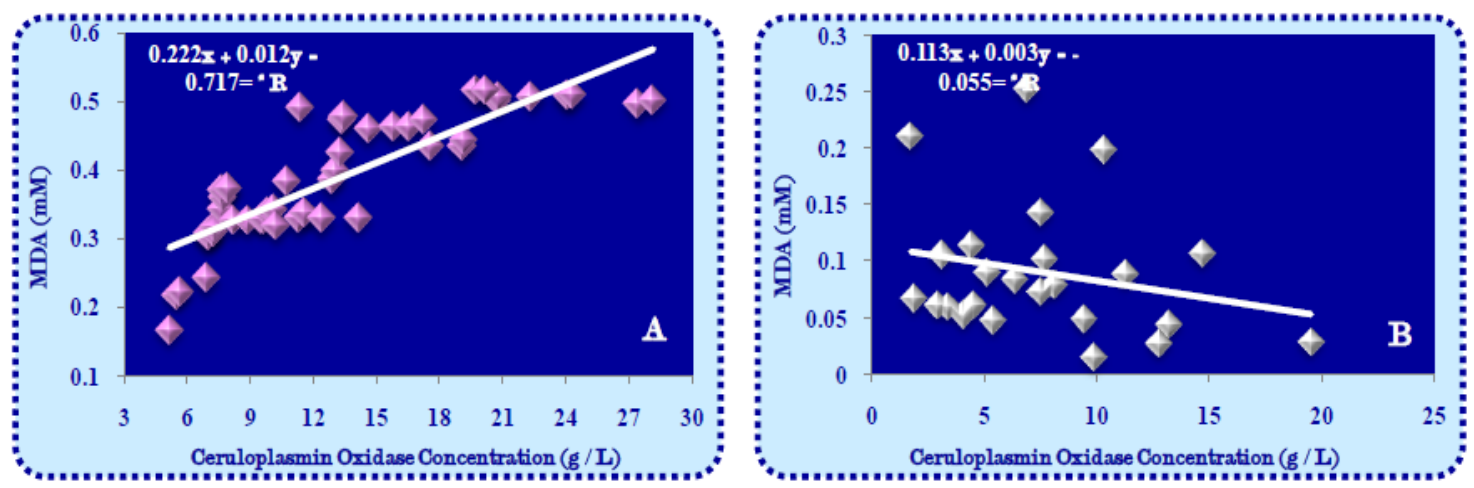

Fig10. Correlation of MDA Concentrations to Cp Concentrations in Sera Samples of (A):Obese and (B): Normal Individuals

For many years ago, malondialdehyde and ceruloplasmin oxidase levels were assessed together to highlight on the cellular injury that could be occur as a result to abnormal condition(s), it is possible to contribute in the violation of oxidation-antioxidants system. The circumstances of estimation were varied to included naturally occurring cases, such as pregnancy ${ }^{(57)}$, aging ${ }^{(58)}$, differing in the life style ${ }^{(59)}$, and the daily mechanical effort expanded ${ }^{(60)}$.

Furthermore, the two parameters (malondialdehyde and ceruloplasmin oxidase) were evaluated for individuals working in the occupations include exposure to the amount of pollution may cause physiological disruption over time ${ }^{(61)}$.

Finally, these parameters were useful predictive, diagnostic and follow up tool for many diseases, like Hypertension $^{(62)}$, Type 2 Diabetes Mellitus ${ }^{(63)}$, Non Acute Hepatitis Virus Type B ${ }^{(22)}$, and cancers ${ }^{(64)}$.Results of the present study agreed with several of the previous studies ${ }^{(62-65)}$, and disagreed with others ${ }^{(66)}$.

In the present work, positive correlation between malondialdehyde and ceruloplasmin oxidase indicate a cellular stress coincide with the occurrence of obesity, but, the process of the accumulation in the outputs of oxidative stress has not yet reached the extent that it inhibits the vital organs, such as liver, from functioning. This finding helps the approval of the observed rise in the levels of malondialdehyde and ceruloplasmin oxidase at the beginning of pathological injuries such as cancer, and then the malondialdehyde continued to rise with a gradual decrease in the levels of ceruloplasmin oxidase harmonize with the progress of infection and spread of the disease ${ }^{(64)}$.

\section{REFERENCES}

[1] U.S. Department of Health and Human Services. [2007]: The Surgeon General's Call to Action to Prevent and Decrease Overweight and Obesity. Overweight in Children and Adolescents. Updated January.

[2] Franco S, \& Marion D. [2011]: International Association for the study of Obesity.

[3] Sesselberg T S, Klein J D, \& O'Connor K G. [2010]: Screening and counseling for childhood obesity: Results from a national survey. J Am Board Fam Med ; Vol. 23, No. 3, p:334-342.

[4] Clinical guidelines on the identification.[1998]: evaluation, and treatment of overweight and obesity in adults: The evidence report. Bethesda, Md.: National Heart, Lung and Blood Institute,; NIH 98-4083.

[5] Sims E A, Danforth E J, Horton E S, Bray G A, Glennon J A, \&Salans L B. [1973]: Endocrine and metabolic effects of experimental obesity in man. Recent ProgHorm Res; Vol. 29, p:457496.

[6] Chagnon Y C, Rankinen T, Snyder E E, Weisnagel S J, Perusse L, \& Bouchard C. [2003]: The human obesity gene map: the 2002 update. Obes Res; Vol. 11, p:313-367.

[7] Richard L, \& Atkinson R. : The management of eating disorders and obesity. second edition. 
Assessment of Concurrent Cellular Oxidative Stress with the Body Weight Gain in Serum of Obese Patients Undergoing to Surgical / Non-Surgical Strategies for Reducing an Excess Weight

[8] Betteridge D J. [2000]: What is oxidative stress. Metabolism. Vol. 49, p: 3-8.

[9] Najah R H, Mohammad A H, \&Ammar R M. [2008]: Effect of atorvastatin on oxidative stress parameters and lipid profile in type 2 diabetic patients. The International Medical Journal. Vol. 7, No. 2, p:43 - 50.

[10] Palmieri B, \&Sblendorio V. [2007]: Oxidative stress tests : overview on reliability and use. European Review for Medical and Pharmacological Sciences. Vol. 11, p:309 - 342.

[11] Machlin L J, \&Bendich A. [1987]: Free radical tissue damage:protective role of antioxidant nutrients. FASEB J. Vol. 1, p: $441-445$.

[12] Halliwell B, \& Whiteman M. [2004]: Measuring reactive species and oxidative damage in vivo and in cell culture: how should you do it and what the results mean. Br J Pharmacol. Vol. 142, p: $231-255$.

[13] Shah S, Iqbal M, Karam J, Salifu M, \&Mcfarlane S I. [2007]: Oxidative stress, glucose metabolism and the prevention of type 2 diabetes: pathophyiological insights. Antioxid Redox Signal. Vol. 9, p: 29 - 911.

[14] Marnette L J. [1999]: Generation of mutagens during arachidonic acid metabolism. Cancer Metastas Rev. Vol. 13, p:303 - 308.

[15] Suwimol J. [2005]: Malondialdehyde (MDA), a lipid oxidation product. Free Radicals in Biology and Medicine. Vol. 77, No. 222, p:1 - 10.

[16] Plastaras J P, Guengerich F P, Nebert D W, \&Marnett L J. [2000]: Xenobiotic-metabolizing cytochromes $P 450$ convert prostaglandin endoperoxide to hydroxyheptadecatrienoic acid and the mutagen, malondialdehyde. J Biol Chem. Vol. 275, p:11784 -11790.

[17] Nair V, \& Turner G A. [1984]: The thiobarbituric acid test for lipid peroxidation: structure of the adduct with malondialdehyde. Lipids. Vol. 19, p :804-805.

[18] Rumley A G, Woodward M, Rumley A, Rumley J, \& Lowe G D. [2004]: Plasma lipid peroxides: relationship to cardiovascular risk factors and prevalent cardiovascular disease. QJM. Vol. 97, p:809-816.

[19] Harris E D. [1991]: Copper transport: an overview. Proc. Soc. Exp. Biol. Med. Vol. 196, p:130140.

[20] Avila V, William H, \&Lokits K.[2009]: Ceruloplasmin levels in human sera form various diseases and their correlation with patient's age and gender. J. Health. Vol. 2, No. 1, p:104 110 .

[21] Joba B, Liliana M, Rita O, \& Maria F M.[2008]: Ceruloplasmin expression by human peripheral blood lymphocytes A new link between immunity and iron metabolism. J Banha et al./Free Radical Biology and Medicine. Vol. 44, p:483 - 492.

[22] Jasim RH. [2011]: Evaluation of Oxidative - Ant oxidative Balance in serum of patients with non acute Hepatitis virus type B. International Conference on Chemistry and Chemical Process. Vol. 10, p:237 - 244.

[23] Graf W D, \&Noetzel M J. [1999]: Radical reactions from missing ceruloplasmin: the importance of a ferroxidase as an endogenous antioxidant. Neurology. Vol. 53, p: 446-447.

[24] Prohanska J R \&Gybina A A.[2004]: Intracellular copper transport in mammals. J Nutr. Vol. 134, p:1003-1006.

[25] Macintyre G, Gutfreund K S, Martin W R, Camicioli R, \& Cox D W. [2004]: Value of an enzymatic assay for the determination of serum ceruloplasmin. J. Lab. Clin. Med. Vol. 144, p: 294-301.

[26] Yagi K.[1982]:Assay for Lipid Peroxide Level and Its Clinical Significance. In: Yagi K Editor Lipid Peroxides in Biology and Medicine, New York; p:233-242.

[27] Rice E W. [1962]: Ceruloplasmin Assay in Serum: Standardization of Ceruloplasmin Activity in Terms of International Enzyme Unit "Standard Methods of Clinical Chemistry". 4th Eddition, Siligson D., New York, Academic press.

[28] Esposito K, Ciotola M, \&Giugliano D.[2006]:Oxidative stress in the Metabolic Syndrome. J. Endocrinol. Invest. Vol. 29, p:791-795. 
[29] Fonseca-Alaniz M H, Takada J, Alonso-Vale M I, \& Lima F B. [2007]:Adipose tissue as an endocrine organ: From theory to practice. J. Pediatr. Vol. 83, No. 5, p:192-203.

[30] Khan N, Naz L, \&Yasmeen G.[2006]: Obesity: An independent risk factor systemic oxidative stress. Park. J. Pharm. Sci. Vol. 19, p: 62-69.

[31] Edwards B A, Sands S A, Owens R L, \& White D P.[2014]: Effects of hyperoxia and hypoxia on the physiological traits responsible for obstructive sleep apnoea. J Physiol. Vol. 592, No. 20, p:4523-4535.

[32] Lockman KA, Htun V, Sinha R, Treskes P, \& Nelson L J. [2016]: Proteomic profiling of cellular steatosis with concomitant oxidative stress in vitro. Lockman et al Lipids in Health and Disease. Vol. 15, No. 1, p:103-114.

[33] Nicholls D G, \& Ferguson F J. [1992] : Bioenergetics: An Introduction to the Chemiosmotic Theory; Academic Press: New York, NY, USA.

[34] Silva H A, Dionizio A S, Fernandes M S, Araujo T T, \& Cestari T M.[2016]: Flouride Intensifies Hypercaloric Diet-Induced ER Oxidative Stress and Alters Lipid Metabolism. J PLOS One. Vol. 11, No. 6, p:1-14.

[35] Debraya F G, Lamberta M \& Mitchell G A.[2008]: Disorders of mitochondrial function. Endocrinology and metabolism. Vol. 20, p:471-482.

[36] Valle A, Oliver J \& Roca P.[2010]: Role of Uncoupling Proteins in Cancer. Cancers. Vol. 2, p:567-591.

[37] Bezaire V, Seifert E L, \& Harper M E. [2007]: Uncoupling protein-3: clues in an ongoing mitochondrial mystery. FASEB J. Vol. 21, p:312-324.

[38] Schrauwen P, \&Hesselink M K.[2004]:The role of uncoupling protein 3 in fatty acid metabolism: protection against lipotoxicity. Proc. Nutr. Soc. Vol. 63, p:287-292.

[39] Ulas T, Buyukhatipoglu H, Idris K, Mehmet S D, \& Sevilay U. [2013]: Evaluation of oxidative stress parameters and metabolic activities of nurses working day and night shifts. Rev Esc Enferm USP. Vol. 47, No. 2, p:471-477.

[40] Francesco P, Costantino S, \&Cosentino F.[2015]: Role of oxidative stress in endothelial insulin resistance. World J Diabetes. Vol. 6, No. 2, p: 326-332.

[41] Pierine D T, Biondo G A, Silva V S \& Correa C R.[2015]: The role of oxidative stress in renal injury related to obesity. Inflammation \& Cell Signaling. Vol. 2, p: 648-6.

[42] Díaz-Castro J, Florido J, Kajarabille N, Prados S, \& Paco C.[2015]: A New Approach to Oxidative Stress and Inflammatory Signaling during Labour in Healthy Mothers and Neonates. Oxidative Medicine and Cellular Longevity. Vol. 2015,p: 8.

[43] Al-Hakeim H K \&Auda F M.(2010): Estimation of the Level of Total Carbonyl and Malondialdehyde in Thalassemic Patients and Study their Correlation with Iron Status Parameters. College of Science, Al-Kufa University , Iraq.

[44] Rodriguez M C, Rosenfold J, \&Tarnopolsky M A.[2003]: Plasma Malondialdehyde increases transiently after ischemic foream exercise. Medicine and Science in Sports and Exercise. Vol. 35, No. 11, p: 1859-1865.

[45] Pihl E, Zilmer K, Kullisaar T, Kairane C, Magi A, \&Zilmer M. [2006]: Atherogenic inflammatory and oxidative stress markers in relation to overweight values in male former athletes. Int. J. Obesity. Vol. 30, p:141-146.

[46] Codoner-Franch P, Tavarez-Alonso S, Murria-Estal R, MegiasVericat J, Tortajada-Girbes M, \& Alonso-Iglesias E. [2011]: Nitric oxide production is increased in severely obese children and related to markers of oxidative stress and inflammation. Atherosclerosis. Vol. 2215, p: 475480.

[47] Zainal I G. [2014]: Estimation activity and partial purification of Ceruloplasmin from sera of patients with chronic renal Failure and healthy subjects. Advances in Biochemistry. Vol. 2, No. 6, p:90-94.

[48] Fleming R E, Whitman I P, \&Gitlin J D.[1991]:Induction of ceruloplasmin gene expression in rat lung during inflammation and hyperoxia. Am. J. Physiol. Vol. 260, p:68-74.

[49] Giner J, Morell M, \& Osorio C. [1972]: Serum levels of ceruloplasmin as an index of the clinical evolution in schizophrenic patients. Rev EspFisiol. Vol. 28, p: 39-42. 
[50] Bharatkumar N P, Robert J D, Suh Y J, Qinzhang Z, Jean-Pierre J, \& Samuel D. [2002]: Ceruloplasmin Regulates Iron Levels in the CNS and Prevents Free Radical Injury. The Journal of Neuroscience. Vol. 22, No. 15, p:6578-6586.

[51] Nobili V, Siotto M, Bedogni G, Rava L, \& Pietrobattista A. [2013]: Levels of Serum Ceruloplasmin Associate With Pediatric Nonalcoholic Fatty Liver Disease. Original Article: Hepatology and Nutrition JPGN. Vol. 56, No. 4, p:370-375.

[52] Sikaris K. [2004]:The clinical biochemistry of obesity. Clin. Biochem. Rev. Vol. 25, p:165-181.

[53] Tajik N, Golpaie A, Keshavars S A, Djalali M, \& Sehet M.[2012]: Decreased Plasma Levels of Ceruloplasmin after Diet Induced Weight Loss in Obese Women. Journal of Endocrinological Investigation. Vol. 35, No. 6, p:566-569.

[54] Arner E, Forrest A R, Ehrlund A, Mejhert N, \& Itoh M. [2014]: Ceruloplasmin Is a Novel Adipokine Which Is Overexpressed in Adipose Tissue of Obese Subjects and in ObesityAssociated Cancer Cells. PLOS ONE. Vol. 9, No. 3, p:80274.

[55] Viorica L A, William H R, \& Kirk L.[2009]: Ceruloplasmin levels in human sera from various diseases and their correlation with patient's age and gender. Health. Vol. 1,No. 2, p:104-110.

[56] Sontakke A N, \& More U.[2004]: Changes In Serum Ceruloplasmin Levels with Commonly Used Methods of Contraception. Indian Journal of Clinical Biochemistry. Vol. 19, NO. 1, p:102-104.

[57] Lekharu R, Pradhan R, Sharma R, \& Sharma D.[2014]: A Study of Lipid Peroxidation and Antioxidant Enzymes in Normal Pregnancy. GCSMS J Med Sci. Vol. 3, No. 1, p:55-56.

[58] Kregel K C, \& Zhang H J. [2007]: An integrated view of oxidative stress in aging: Basic mechanisms, functional effects, and pathological considerations. Am. J. Physiol. Regul. Integr. Comp. Physiol. Vol. 292, p:18-36.

[59] Dato S, Crocco P, D’Aquila P, Rango F, \& Bellizzi D. [2013]: Exploring the Role of Genetic Variability and Lifestyle in Oxidative Stress Response for Healthy Aging and Longevity. Int. J. Mol. Sci. Vol. 14, p:16443-16472.

[60] Watson T A,MacDonald-Wicks L K, \&Garg M L.[2005]: Oxidative stress and antioxidants in athletes undertaking regular exercise training. Int. J. Sport Nutr. Exerc. Metab. Vol. 15, p:131146.

[61] Orhan H.[2000]: Biotransformtion of Inhalational Anesthetics and development of biomarkers determining their toxicity. Department of Chemistry,The College of Science, University of Ankara. Ph. D. thesis.

[62] Abbas R K. [2012]: Clinical Comparative Study for the Effects of Antihypertensive Drugs on Oxidative Stress and Lipid Profile in Thi-Qar/Iraq. Department of Chemistry, The College of Science, University of Thi-Qar.

[63] Kumari M D, \&Sankaranarayana T.[2014]: Evaluation of Oxidative Stress in Type 2 Diabetes Mellitus Patients. IOSR Journal of Dental and Medical Sciences. Vol. 13, No. 5, p:46-50.

[64] Gadjeva V, Kutchukova D, Aladjov E, \&Georgieva R.[2005]: Correlation Between Plasma Malondialdehyde And Ceruloplasmin Activity In Patients With Malignant Haematological Diseases. Trakia Journal of Sciences. Vol. 3, No. 2, p:29-33.

[65] Voiculescn V, Luca N, Hategan D, \&Alecu C. [1984]:Onset-related values of serotonin, ceruloplasmin and 5-HIAA in patients with MS. Immunological and Clinical Aspects of Multiple Sclerosis. P:421.

[66] Aksoya H, Koruk M, \&Akcay F.[2003]: The Relationship Between Serum Malondialdehyde and Ceruloplasmin in Chronic Liver Disease. Turk J biochem. Vol. 28, No. 2, p:32-34 